Running head: GENERAL EDUCATION DIFFERENCES

\title{
The Effect of Teaching General Education Courses on Deep Approaches to Learning: How Disciplinary Context Matters
}

\author{
Thomas F. Nelson Laird \\ Assistant Professor \\ Indiana University Center for Postsecondary Research \\ 1900 East Tenth Street \\ Eigenmann Hall, Suite 419 \\ Bloomington, IN 47406-7512 \\ tflaird@indiana.edu \\ Phone: 812.856 .5824 \\ Amy K. Garver \\ Project Associate \\ Indiana University Center for Postsecondary Research
}

Paper presented at the Annual Forum of the Association for Institutional Research, May 24-28, 2008

Seattle, WA 


\begin{abstract}
Building on work examining differences in the emphasis faculty place on effective educational practices, this study uses data from over 8,000 faculty members from the 2007 Faculty Survey of Student Engagement to explore how disciplinary area moderates the effect of teaching a general education course (GEC) on the emphasis faculty place on deep approaches to learning. Results suggest that the effect of GECs is strongest in hard-applied-life fields and weakest in hard-purelife and soft-applied-life fields, suggesting that proponents of general education reform need to temper their efforts by a clear understanding of disciplinary differences.
\end{abstract}


The Effect of Teaching General Education Courses on Deep Approaches to Learning: How Disciplinary Context Matters

In today's colleges and universities, where there is an ever present focus on specialization, general education courses (GECs) expose students to a variety of disciplinarybased content and practices in order to provide a shared breadth of education for all (Association of American Colleges and Universities [AAC\&U], 2005; Ratcliff, Johnson, La Nasa, \& Graff, 2001). As a collective unit, GECs intend to help students develop valuable skills, such as integrative thinking, communication, quantitative reasoning, and critical thinking, that are crucial for life-long learning. In essence, it is the assumption that GECs build a foundation of knowledge needed for graduates to be effective citizens in a fast-paced, interconnected world.

With increasing pressure to demonstrate their effectiveness (Kuh, 2007), higher education institutions and their constituent departments and faculty have expended considerable energy assessing and evaluating GECs. Whether across a system (this is relatively rare), within a single institution (more common), or based on a small number of courses (most common), the focus of this work, not surprisingly, is almost always on predicting student outcomes (e.g., Choi, 2005; Kramer, 2006; Mahoney \& Schamber, 2004; Nelson Laird, Engberg, \& Hurtado, 2005; it is also important to note that much of this work probably does not make it into the published literature). Most of the studies examine whether a single course or a group of general education courses yield intended positive effects on students' grades, retention, critical thinking, or readiness for engaged citizenship, broadly defined.

With such a strong focus on student outcomes assessment, research into differences between GECs and non-GECs rarely taps faculty members as a source of information. Consequently, important factors in the production of student learning outcomes, like faculty 
teaching practices, are largely ignored in these assessments. With careful examination, differences in the ways GECs and non-GECs are taught could help explain differences found in student outcomes as well as identify actionable areas where faculty can improve their courses.

To partially address this gap, a recent study based on nearly 11,000 faculty members from 109 institutions showed that faculty who taught GECs placed greater emphasis on deep approaches to learning, active classroom practices, and diverse interactions among students relative to their colleagues teaching non-GECs (Nelson Laird, Niskodé, \& Kuh, 2006). The study also showed that, compared to colleagues teaching non-GECs, faculty members teaching GECs placed greater emphasis on developing intellectual skills and personal and social responsibilities.

While such findings are encouraging for proponents of general education and add to our understanding of why GECs often promote certain outcomes to a greater degree than non-GECs, there are reasons to doubt the stability of the gap between GECs and non-GECs in teaching practices across disciplinary areas. Differences in disciplinary culture affect the ways faculty members think about their academic tasks, including teaching (Becher \& Trowler, 2001). A large body of research suggests that these cultural and philosophical differences lead to the disciplinary differences observed in collegiate teaching practices (Biglan, 1973a,b; Braxton \& Hargens, 1996; Hativa \& Marincovich, 1995; Smart, Feldman, \& Ethington, 2000; Smart \& Umbach, 2007; Stark \& Lattuca, 1997). Particularly relevant to the current study, evidence suggests that faculty emphasis on deep approaches to learning varies considerably by disciplinary area (Nelson Laird, Shoup, Kuh, \& Schwarz, in press).

Yet, beyond creating differences in the ways all courses are taught within a field, faculty members' disciplinary-rooted goals for instruction and philosophies of education (Lattuca \& Stark, 1994; Stark \& Lattuca, 1997) suggest that the meaning and importance attached to general 
education may vary widely from discipline to discipline. In fact, faculty members from fields with a low degree of consensus regarding theory, methods, and practices (i.e., "soft" fields according to Biglan, 1973a,b) place greater importance on providing a broad general education than their colleagues in high consensus fields (i.e. "hard" fields), where teaching philosophies place greater emphasis on career preparation (Braxton \& Hargens, 1996; Gaff \& Wilson, 1971).

A field's orientation toward general education will likely affect how GECs in that field are taught. Because orientations toward general education vary by disciplinary area, the difference in practices between GECs may be larger in some fields and smaller in others, a possibility that was not tested for in the earlier study of faculty teaching practices in GECs and non-GECs (Nelson Laird, Niskodé, \& Kuh, 2006). Thus, the purpose of the present study is to examine how the teaching differences between GECs and non-GECs vary by disciplinary area.

For our study, we focus on the emphasis faculty place on deep approaches to learning as a particular set of teaching practices. Deep approaches to learning are avenues for students to engage in their academic work in a way that reflects a personal commitment to strive for a greater understanding of the material and foundational concepts (Ramsden, 2003; Tagg, 2003). Faculty members encouraging deep approaches to learning emphasize analyzing and synthesizing information, integrating information and concepts from multiple contexts, and reflecting on one's own learning (Nelson Laird et al., in press). In contrast, surface approaches to learning emphasize memorizing material in an attempt to avoid failure on some kind of test (Biggs, 1989; Bowden \& Marton, 1998; Tagg, 2003). These approaches are important to study because evidence suggests that utilization of a deep approach leads to improved student outcomes (Biggs, 1988, 1989; Entwistle \& Ramsden, 1983; Nelson Laird et al., in press; Prosser \& Millar, 1989; Ramsden, 2003). Further, a recent study demonstrated that, at least for self- 
reported gains, grades, and satisfaction, the benefits of using these approaches are fairly consistent across fields (Nelson Laird et al., in press). In other words, these approaches are beneficial regardless of one's field.

In that same study, meaningful differences were found between disciplinary areas in the amount faculty emphasized deep approaches to learning (Nelson Laird et al., in press). That study utilized Biglan's (1973a,b) categorization and found meaningful differences between the eight resulting disciplinary areas (hard-pure-life, hard-pure-non-life, hard-applied-life, hardapplied-non-life, soft-pure-life, soft-pure-non-life, soft-applied-life, and soft-applied-non-life) on the overall emphasis on deep approaches to learning scale as well as its three component subscales: higher-order learning, integrative learning, and reflective learning.

Study Purpose

Building from earlier work (Nelson Laird, Niskodé, \& Kuh, 2006; Nelson Laird et al., in press), this study was designed to determine whether the gap in faculty members' emphasis on deep approaches to learning between GECs and non-GECs is consistent across disciplinary areas, as measured by Biglan's (1973a,b) eight categories. Further, if inconsistencies are found, this study will document the extent of those inconsistencies and identify any possible patterns across our four measures of faculty emphasis on deep approaches to learning: the overall scale and its three sub-scales.

\section{Methods}

\section{Data Source and Institutional Participation}

The data for this study come from the 2007 administration of the Faculty Survey of Student Engagement (FSSE), an annual survey of faculty teaching undergraduates at baccalaureate-granting colleges and universities across the country. FSSE is designed to 
complement the National Survey of Student Engagement by asking faculty about the value and emphasis they place on activities that prior research has connected to valued outcomes (Chickering \& Gamson, 1987; Kuh, 2001, 2003; Pascarella \& Terenzini, 2005). Institutions that participate in NSSE choose to participate in FSSE and select their own sample of faculty to survey. Given that the focus of the survey is on undergraduate teaching and learning, institutions are encouraged to submit samples containing only for those faculty members who teach undergraduates. The majority of institutions survey all undergraduate teaching faculty. In 2007, FSSE received responses from faculty members at 162 institutions (47\% of faculty members invited to participate responded). In this year, institutions were given the option to choose whether some of the questions were course-based or based on faculty members' understanding of the typical student they taught. Sixty-two percent (101) administered coursebased questions to their faculties and 38\% (61) administered typical student questions (for more information on the survey options visit www.fsse.iub.edu). However, only data from the 101 institutions that chose the course-based option were used in this study due to our focus on faculty practices in GECs and non-GECs (GEC status is only available for faculty responding to the course-based questions).

Although not sampled to represent all U.S. colleges and universities, the 101 institutions capture a wide cross-section of U.S. baccalaureate-granting institutions. For example, of the 101 institutions, $35 \%$ are doctoral, about $46 \%$ are master's level, $17 \%$ are baccalaureate level. However, four-year public (73\%) institutions represent a large majority of the sample.

\section{Sample}

After limiting to the 101 institutions, dropping faculty from fields that do not fit into Biglan's (1973a,b) categories, and deletion for missing data, the sample for this study consists of 
8,030 faculty members. Approximately $44 \%$ were female, $76 \%$ were White ( $4 \%$ African American, $5 \%$ Asian, $4 \%$ Hispanic, $<1 \%$ Native American, $1 \%$ other racial/ethnic background, and $1 \%$ multi-racial or ethnic), and about $85 \%$ were working full-time. In addition, about $24 \%$ were lecturers or instructors, $27 \%$ were assistant professors, $23 \%$ were associate professors, and $26 \%$ were full professors. The average faculty member taught 5 courses in the current academic year and had 16 years of experience teaching at the collegiate level. In this study, 59\% responded regarding an upper division course (mostly juniors and seniors) and 50\% responded about a course that met a general education requirement.

Faculty members were also asked to identify the field of study within which the course was being offered. Courses from 61 disciplinary areas were included. Based on previous work (Biglan, 1973a,b; Braxton \& Hargens, 1996; Nelson Laird et al., in press; Stoecker, 1993), areas were mapped into Biglan's original categories (see Table 1). Of the faculty members in the sample, $8 \%$ were in hard-pure-life fields, $13 \%$ were in hard-pure-non-life fields, and $1 \%$ were in hard-applied-life fields, $4 \%$ were in hard-applied-non-life fields, $13 \%$ were in soft-pure-life fields, $30 \%$ were in soft-pure-non-life fields, and $13 \%$ were in soft-applied-life fields, and $17 \%$ were in soft-applied-non-life fields.

\section{Measures}

The course-based survey option asked faculty to respond to a variety of questions based on a particular course taught during the 2006-07 academic year. Faculty identified whether their course was a GEC, what field the course was taught in, and the level of emphasis on deep approaches to learning. In the study, GEC status was a simple dichotomous indicator; a course was either a GEC or a non-GEC.

To explore disciplinary effects, we relied on the same grouping of fields used by Nelson 
Laird et al. (in press) to separate faculty by the field in which their course was taught. This breakdown of fields by Biglan's (1973a,b) three dimensions is given in Table 1. As Table 1 illustrates, using these three dimensions, the fields can be divided into eight groups: hard-purelife (HPL), hard-pure-non-life (HPN), hard-applied-life (HAL), hard-applied-non-life (HAN), soft-pure-life (SPL), soft-pure-non-life (SPN), soft-applied-life (SAL), and soft-applied-non-life (SAN). Dichotomous measures representing these eight groups were used in our analyses.

The items in Table 2 combine to form a reliable measure of faculty emphasis on student participation in activities that represent a deep approach to learning (alpha $=0.75)$. These teaching emphases are divided into three sub-scales_-higher order learning, integrative learning, and reflective learning - that correspond to the deep approaches to learning sub-scales from NSSE (see Nelson Laird, Shoup, \& Kuh, 2006) and reflect areas tapped by other student measures of deep approaches to learning (Biggs, 1987; Biggs, Kember \& Leung, 2001; Ramsden \& Entwistle, 1981, Entwistle \& Ramsden, 1983).

The emphasis on higher order learning subscale $($ alpha $=0.73)$ focuses on the amount faculty believe that their courses emphasize advanced thinking skills such as analyzing the basic elements of an idea, experience, or theory and synthesizing ideas, information, or experiences into new, more complex interpretations.

The emphasis integrative learning subscale $($ alpha $=0.69)$ contains items that center around the amount faculty emphasize student participation in activities that require integrating ideas from various sources, including diverse perspectives in their academic work and discussing ideas with others outside of class.

The importance of reflective learning sub-scale $($ alpha $=0.81)$ addresses the notion that students can learn and expand their understanding by investigating their own thinking and then 
applying their new knowledge to their lives. Items ask how important faculty believe it is for students in their course to try to better understand someone else's views, examine the strengths and weaknesses of their positions, and learn something that changes the way they understand an issue or concept.

In the analyses described below, a set of variables was used to control for the same faculty, course, and institutional characteristics that were used in previous studies (Nelson Laird, Niskodé, \& Kuh, 2006; Nelson Laird et al., in press). Descriptions of these variables can be found in Appendix A.

\section{Data Analyses}

Four regression models were run to determine the effects of teaching a GEC on the emphasis on deep approaches to learning scale and its sub-scales. Analyses included a dichotomous variable indicating whether a faculty member taught a GEC or not and seven dichotomous measures capturing the eight discipline categories that result from Biglan's (1973a,b) categorization (soft-applied-non-life was the reference category). Control variables included faculty (e.g., gender, race, years teaching, rank, and course load), course (e.g., course level), and institutional characteristics (control and Carnegie classification). In order to examine whether the effect of teaching a general education course varied by disciplinary area, we regressed each dependent measure on the full set of independent measures, including seven interaction terms equal to the product of general education status and each of the Biglan's categories. All dichotomous independent variables were mean centered prior to running the analyses. The interaction terms were products of the centered discipline indicators and the centered general education variable.

\section{Limitations}


The primary limitations of this study involve layers of choice. Since institutions chose whether or not to participate in FSSE in 2007, our sample is essentially a convenience sample. This suggests that caution should be used when generalizing our findings to faculty at other institutions of higher education. Fortunately, the 101 institutions included in this study represent a wide cross-section of four-year colleges and universities where, in nearly all instances, all undergraduate teaching faculty or simply all faculty members were surveyed. While studies done on a subgroup of institutions (e.g., selective liberal arts colleges) may produce quite different results, we would be surprised if studies done on faculty from U.S. institutions in general did not find similar results.

In addition, faculty chose whether or not to respond once invited to participate. Even though response rates are generally strong (nearly all above $30 \%$ ). Non-response bias is a potential issue, which again suggests caution about generalizing. We did not adjust for nonresponse because FSSE does not solicit information from institutions about the characteristics of faculty in the institutional samples. Still, faculty respondents compare favorably to nationally representative samples of faculty on many characteristics (FSSE, 2007).

Finally, faculty members were given a choice about which course they would answer questions. While course characteristics (e.g., upper or lower division and size) indicated a wide cross-section of course types covered in the survey, there is the possibility that faculty members' choices were not entirely random. For example, there could be a bias toward selecting smaller, lower division courses, when possible. This suggests that caution should also be used when generalizing beyond the courses covered by faculty responses.

Results

Consistent with previous work (Nelson Laird, Niskodé, \& Kuh, 2006; Nelson Laird et al., 
in press), the results from our study suggest that, in general, faculty who teach GECs tend to emphasize deeper approaches to learning more often than their colleagues teaching non-GECs (see Table 3). In addition, the amount of emphasis faculty members place on deep approaches to learning varies considerably by academic discipline. However, the effect of GEC status is inconsistent across disciplinary areas, suggesting that the amount that GEC status affects faculty members' teaching depends on the field in which they teach.

In the following paragraphs we report the findings related to the effects of GEC status and academic discipline on faculty emphasis of deep approaches to learning. We explain the results of the regression models and then highlight how the means and adjusted means (adjusted means are those derived from our models) differ for the overall scale and sub-scales by GEC status across disciplinary groups.

Regression Models

As in other studies (Nelson Laird, Niskodé, \& Kuh, 2006; Nelson Laird et al., in press), the models explained a decent amount of variance for the overall scale $\left(\mathrm{R}^{2}=0.22\right)$, emphasis on integrative learning $\left(\mathrm{R}^{2}=0.23\right)$, and importance of reflective learning $\left(\mathrm{R}^{2}=0.22\right)$. The explained variance for emphasis on higher-order learning was quite low $\left(R^{2}=0.06\right)$, primarily because disciplinary area is a weaker predictor for this sub-scale. Still, in all instances models were significant at $p<0.001$.

Table 3 gives the coefficients and standard errors for the key study variables for each regression model (results for the control variables were omitted due to space, but are available from the authors upon request). Since the dependent variables were standardize prior to the analyses, the coefficients for the dichotomous independent variables can be interpreted as standardized mean differences with pooled standard deviations (i.e. effect sizes). The coefficients 
for the interaction terms can be interpreted as differences in the effect sizes relative to the reference group (soft-applied-non-life).

The results show that, holding all else constant, faculty teaching GECs emphasize deep approaches to learning, on average, more than their colleagues teaching non-GECs. The difference was near a quarter of a standard deviation for the overall scale as well as the emphasis on integrative learning and importance of reflective learning sub-scales. The difference was smaller for high-order learning ( 0.15 of a standard deviation) and non-significant ( $p>0.05)$.

Disciplinary differences were significant in all of the models. The difference between the lowest scoring group (either hard-pure-life or hard-pure-non-life) and the highest scoring group (either soft-applied-life or the soft-pure fields) ranged from about a half of a standard deviation for faculty emphasis on higher-order learning to over a full standard deviation on the overall scale as well as the two other sub-scales.

The interaction terms were used in this study to determine whether the GEC effect varied by disciplinary area. With at least one significant interaction term in three out of four models, our results suggest that discipline does moderate the effect of GEC status. Even for reflective learning, where no coefficient is significant, the difference in effect between hard-applied-life fields and soft-pure-life fields is over two-tenths of a standard deviation (an amount that would be significant if the reference group were changed). To illustrate and clarify the meaning of the interaction terms, we used the regression models to estimate mean scores for GECs and nonGECs in each disciplinary area controlling for the other variables in the model (the adjusted means in Table 4). Mean Differences for the Overall Deep Approaches to Learning Scale

Table 4 contains the adjusted means for the overall deep learning scale and sub-scales by 
GEC status for each of the eight Biglan categories. Because the estimated means were calculated based on the regression results in Table 3, they control for the effects of the other faculty, course, and institutional characteristics in the models. For comparative purposes, the unadjusted means and standard deviations are also given in Table 4 for the same 16 groups. The unadjusted means are important because a large difference between adjusted and unadjusted means in a disciplinary area suggests that faculty in that group have characteristics that affect their scores. For example, women faculty members generally emphasize deep approaches to learning more than their male counterparts. So, in fields with an overrepresentation of women, the adjusted mean would likely be lower than the unadjusted mean (e.g., soft-applied-life). Additionally, the unadjusted mean score is important because it represents the level of emphasis on deep approaches to learning experienced by students. To illustrate, again because women tend do emphasize deep approaches to learning more, students in fields with more women will likely experience greater emphasis on deep approaches to learning. The adjusted score is important because it gives an estimate of the level of emphasis that is attributable to the GEC and non-GEC courses in a disciplinary area rather than the other characteristics in the model.

After controls, the largest estimated mean difference between faculty teaching GECs and non-GECs was found in the hard-applied-life fields, where faculty teaching GECs averaged onetenth of a standard deviation below the grand mean (-0.13) and faculty teaching non-GECs averaged one-half a standard deviation below the grand mean $(-0.53)$. The difference between the groups, two-fifths standard deviation (0.40), amounts to a substantial difference in the emphasis faculty place on deep approaches to learning in the two types of courses.

The differences were near zero (0.06 to 0.08$)$ for faculty in hard-pure-life, soft-appliedlife, and hard-pure-non-life fields, but were modest in size ( 0.14 to 0.23$)$ for faculty in soft-pure- 
non-life, soft-pure-life, hard-applied-non-life, and soft-applied-non-life fields. Interestingly, the unadjusted mean differences show that in five disciplinary areas (hard-pure-life, hard-pure-nonlife, soft-pure-life, soft-pure-non-life, and soft-applied-life), non-GECs averaged greater or near equal emphasis on deep approaches to learning (differences of -0.08 to 0.03) compared to GECs. Estimated Means for the Emphasis on Higher-Order Learning Sub-Scale

More dramatically, prior to faculty, course, and institutional controls, faculty in the same five disciplinary areas as above averaged greater emphasis on higher-order learning in non-GECs than in GECs (differences of -0.20 to -0.02). However, after controls entered the model, estimated mean differences for four of the five disciplinary areas all got closer to zero (-0.15 to 0.01), suggesting that differences between the groups in terms of their other characteristics, in part, explain the GEC status difference. For, soft-pure-life fields (where the difference goes from -0.02 to 0.08$)$, the opposite was true.

The largest gap between estimated means was found again among hard-applied-life fields. Among faculty teaching in two closely related fields, soft-applied-life and soft-appliednon-life the differences by GEC status were of near equal size but in opposite directions. Estimated means for faculty teaching GECs in soft-applied-non-life fields was modestly higher than the grand mean (est. mean $=0.12$ ) and their colleagues teaching non-GECs emphasized higher-order learning less (est. mean $=-0.04$ ). The corresponding gap for soft-applied-life fields resulted from a relatively high average for non-GECs (est. mean $=0.19$ ) and a near zero average for GECs (est. mean $=0.04)$.

Estimated Means for the Emphasis on Integrative Learning Sub-Scale

The pattern of findings for faculty emphasis on integrative learning mirrors closely the findings for the overall scale. The unadjusted means for faculty in the hard-pure-life, hard-pure- 
non-life, and soft-applied-life fields were negative $(-0.20$ to -0.06$)$ and the adjusted means for those groups were close to zero ( -0.03 to 0.06$)$. The other fields have modestly sized differences for both unadjusted and adjusted means. However, faculty emphasis on integrative learning is the only sub-scale where the largest unadjusted mean difference was found in a group other than the hard-applied-life fields. Faculty teaching GECs in the soft-pure-life fields scored over a third of a standard deviation (0.35) higher than their colleagues teaching non-GECs before controls, but, after controls were introduced, the largest difference was still found in the hard-applied-life fields.

Estimated Means for the Importance of Reflective Learning Sub-Scale

There are three noteworthy things about the pattern of results for the importance of reflective learning scale. First, unlike the other sub-scales, this was the only scale where GEC averages were above non-GEC averages for all eight disciplinary areas for both unadjusted $(0.05$ to 0.39$)$ and adjusted means ( 0.12 to 0.33$)$. Second, the sizes of the differences were most consistent for this sub-scale, especially for the fields outside of hard-applied-life. Finally, this was the first time the unadjusted mean differences for the hard-pure-life, hard-pure-non-life, and soft-applied-life fields were positive and the adjusted mean differences non-trivial $(>0.10)$.

\section{Discussion and Implications}

AAC\&U (2007) suggests that institutions of higher education need to shift their thinking about the meaning of general education. In the twentieth century, scholars and policy makers viewed GECs as the source of liberal learning for all students. In the twenty-first century, they argue, liberal learning should be viewed as a set of necessary outcomes being promoting collaboratively by GECs and courses in the major. Making this shift and successfully promoting liberal learning will require campuses to undertake curricular reform efforts as well as efforts 
aimed at improving teaching practices by faculty across disciplinary areas. The results of our study suggest that one's approach to reform likely needs to be tempered by understanding disciplinary differences in pedagogy such as those illustrated in our findings. Reformers should account for differences between and within disciplinary areas. As a simple illustration, while it may be equally important to address relatively low emphasis on deep approaches to learning in hard-pure-life and hard-applied-non-life fields, faculty in the latter category need to explore how teaching GECs changes their practices to a greater degree than their colleagues in the former category.

The results of this study suggest three areas worth understanding and further exploration in terms of the differences observed between GECs and non-GECs by disciplinary area. First, there are disciplinary areas where the effect of GEC status was inconsistent compared to other fields and inconsistent across the measures of faculty emphasis on deep approaches to learning. For example, in the hard-pure fields, higher-order and integrative learning were generally emphasized more in non-GEC courses, but reflective learning was emphasize more in GEC courses. This was particularly the case when controls were not used. For soft-pure-life fields the GEC effect appeared to be strongest for integrative learning, while it was strongest for reflective learning in the soft-pure-non-life fields. Our findings do not suggest a rationale for why these inconsistencies exist. It is not the case, for example, that all hard fields show a similar pattern or that applied-non-life fields have similar patterns of findings. Thus, understanding the pattern of effects within each of the eight categories is an area for future research that could help institutions development successful approaches for instructional improvement in different disciplinary areas.

Second, though we found inconsistencies in the GEC effect, there were disciplinary areas 
where the effect was relatively consistent. For the hard-applied and soft-applied-non-life fields, the average GEC emphasized higher-order, integrative, and reflective learning more than nonGECs in the same field, whether or not scores were adjusted for faculty, course, and institutional characteristics. This suggests that these disciplinary areas may have similar understandings of the value of general education and the need to adapt one's teaching practices depending on GEC status. Further research is needed to see if this relative consistency holds when exploring other teaching practices (e.g., active and collaborative classroom practices).

Third, and finally, the GEC effect was altered in nearly all fields once we accounted for faculty, course, and institutional characteristics. In some fields the effect would be accentuated, in others it was diminished, and in others it was flipped from negative to positive. For example, the effect of GEC status generally got a bit smaller for hard-applied fields when controls were introduced. The opposite was true for soft-applied-non-life fields. In other fields, there was a mix of accentuation, diminishment, and flipping. This all suggests that the characteristics of the faculty teaching a course and the characteristics of the course matter to the effect of GEC status. Consider the GEC and non-GEC averages in soft-pure-non-life fields. Without controls the averages are practically identical for emphasis on integrative learning, suggesting that students in the two sets of courses receive nearly equal emphasis on integrating ideas and concepts from multiple sources and courses in GECs and non-GECs. However, if the characteristics of the faculty and courses were made equal, our model suggests that the GECs in that disciplinary area would then emphasize integrative learning more than non-GECs. This highlights how choices about who teaches a course and in what format the course is delivered can affect the teaching practices used. If done wisely, the choices can aid program or institutional goals. If done unwisely, the choices can hinder educational efforts. 
This also highlights the need for assessment and improvement efforts to account for the characteristics of the faculty and courses being targeted. For example, the approach to reform in a biology department where the GECs are taught to large sections by predominantly male tenuretrack faculty will likely need to be different than the approach used for a largely female group of lecturers and instructors teaching GECs in small sections in another biology department.

\section{Conclusion}

The results of this study suggest that faculty approaches to teaching GECs vary by disciplinary area, which has important implications for how to approach curricular reform and instructional improvement on college and university campuses. Faculty and administrators involved in such efforts should be grounded in an understanding of disciplinary differences in teaching practices as well as an understanding of how the disciplinary context may affect differences between different types of courses, particularly GECs and non-GECs. This study was largely exploratory in the sense that we sought to understand where variation in the GEC effect existed and, when it did, to document the size of that variation. We have established that variation exists, but much more work needs to be done to understand the other areas in which this type of variation is found and to test reasons for its existence. Equipped with the results of such work and an approach nuanced by understanding the effects of discipline, educators can be more successful in their efforts to improve undergraduate education. And, as a result, increase students' preparedness for the 21 st century workforce and foster greater civic responsibility. 


\section{References}

Association of American Colleges and Universities (2005). The art \& science of assessing general education outcomes and contemporary understandings of liberal education. Washington, DC: Author.

Association of American Colleges and Universities (2007). College learning for the new global century: A report from the National Leadership Council for Liberal Education \& America's Promise. Washington, DC: Author.

Becher, T. \& Trowler, P. R. (2001) Academic tribes and territories: Intellectual enquiry and the cultures of disciplines (2nd ed.). Buckingham, UK: SRHE and Open University Press.

Biggs, J.B. (1987). Student approaches to learning and studying. Hawthorn, Victoria: Australian Council for Educational Research.

Biggs, J.B. (1988). Approaches to learning and to essay writing. In R.R. Schmeck (ed.) Learning strategies and learning styles (pp. 185-228). New York, NY: Plenum.

Biggs, J.B. (1989). Approaches to the enhancement of tertiary teaching. Higher Education Research and Development, 8, 7-25.

Biggs, J.B., Kember, D., \& Leung, D.Y.P. (2001). The revised two-factor Study Process Questionnaire: R-SPQ-2F. British Journal of Educational Psychology, 71, 133-149.

Biglan, A. (1973a) The characteristics of subject matter in different scientific areas. Journal of Applied Psychology, 57, 195-203.

Biglan, A. (1973b) Relationships between subject matter characteristics and the structure and output of university departments. Journal of Applied Psychology, 57, 1204-1213.

Bowden, J. \& Marton, F. (1998). The university of learning. London, England: Kogan Page.

Braxton, J. M. \& Hargens, L. L. (1996). Variation among academic disciplines: Analytical frameworks and research. In J. Smart, W.J. Tierney (Eds.), Higher education: Handbook of research and theory, XI, (pp. 1-46). New York: Agathon Press.

Chickering, A. W. \& Gamson, Z. F. (1987). Seven principles for food practice in undergraduate education. AAHE Bulletin 39(7), 3-7.

Choi, N. (2005). Self-efficacy and self-concept as predictors of college students' academic performance . By: Choi, Namok. Psychology in the Schools, v42 n2 p197-205 Feb 2005.

Entwistle, N. J. \& Ramsden, P. (1983). Understanding student learning. London: Croom Helm.

Faculty Survey of Student Engagement (2007). FSSE 2007 overview. Bloomington, IN: Center for Postsecondary Research. 
Gaff, J. G. \& Wilson, R. C. (1971). Faculty cultures and interdisciplinary studies. Journal of Higher Education, 42(3), 186-201.

Hativa, N. \& Marincovich, M. (Eds.) (1995). Disciplinary differences in teaching and learning: Implications for practice. New Directions for Teaching and Learning No. 64. San Francisco: Jossey-Bass.

Kuh, G. D. (2001). Assessing what really matters to student learning: Inside the National Survey of Student Engagement. Change, 33(3), 10-17, 66.

Kuh, G. D. (2003). What we're learning about student engagement from NSSE. Change, 35(2), 24-32.

Kuh, G. D. (2007). Risky business: Promises and pitfalls of institutional transparency. Change, $39(5), 30-35$.

Kramer, P. I. (2006). Assessment and the fear of punishment: How the protection of anonymity positively influenced the design and outcomes of postsecondary assessment. Assessment \& Evaluation in Higher Education, 31(5), 597-609.

Lattuca, L. \& Stark, J. (1994) Will disciplinary perspectives impede curricular reform?. Journal of Higher Education, 65, 401-426.

Mahoney, S. L. \& Schamber, J. F. (2004). Exploring the application of a developmental model of intercultural sensitivity to a general education curriculum on diversity. Journal of General Education, 53(3-4), 311-334.

Nelson Laird, T. F., Engberg, M. E., \& Hurtado, S. (2005). Modeling accentuation effects: Enrolling in a diversity course and the importance of social action engagement. Journal of Higher Education, 76(4), 448-476.

Nelson Laird, T. F., Niskodé, A. S., \& Kuh, G. D. (2006, November). General education courses and the promotion of essential learning outcomes. Paper presented at the Annual Meeting of the Association for the Study of Higher Education, Anaheim, CA.

Nelson Laird, T. F., Shoup, R., \& Kuh, G. D. (2006, May). Measuring deep approaches to learning using the National Survey of Student Engagement. Paper presented at the Annual Forum of the Association for Institutional Research, Chicago, IL.

Nelson Laird, T. F., Shoup, R., Kuh, G. D., \& Schwarz, M. J. (in press). The effects of discipline on deep approaches to student learning and college outcomes. Research in Higher Education.

Pascarella, E. T. \& Terenzini, P. T. (2005). How college affects students: A third decade of research. San Francisco: Jossey-Bass.

Prosser, M. \& Millar, R. (1989). The "how" and "what" of learning physics. European Journal of Psychology of Education, 4, 513-528. 
Ramsden, P. (2003). Learning to teach in higher education. London: Routledge Falmer.

Ramsden, P. \& Entwistle, N.J. (1981). Effects of academic departments on students' approaches to studying. British Journal of Educational Psychology, 51, 368-383.

Ratcliff, J. L., Johnson, D. K., La Nasa, S. M., \& Gaff, J. G. (2001). The status of general education in the year 2000: Summary of a national survey. Washington, DC: Association of American Colleges and Universities.

Smart, J. C., Feldman, K. A., \& Ethington, C. A. (2000). Academic disciplines: Holland's theory and the study of college students and faculty. Nashville: Vanderbilt University Press.

Smart, J. C. \& Umbach, P. D. (2007). Faculty and academic environments: Using Holland's theory to explore differences in how faculty structure undergraduate courses. Journal of College Student Development, 48(2), 183-195.

Stoecker, J. L. (1993). The Biglan classification revisited. Research in Higher Education, 34(4), 451-464.

Stark, J. S. \& Lattuca, L. R. Shaping the college curriculum: Academic plans in action. Boston, MA: Allyn and Bacon.

Tagg, J. (2003). The learning paradigm college. Boston, MA: Anker. 
Appendix

Independent Variables

\begin{tabular}{|c|c|}
\hline Name & Description \\
\hline \multicolumn{2}{|l|}{ Faculty characteristics } \\
\hline Gender & $0=$ Male $; 1=$ Female \\
\hline Ethnicity $^{\mathrm{a}}$ & $\begin{array}{l}\text { African American, American Indian, Asian American, White }{ }^{\mathrm{b}} \text {, } \\
\text { Hispanic, Other, Multiple ethnic identifications, Prefer not to } \\
\text { identify }\end{array}$ \\
\hline Foreign Citizenship & $0=\mathrm{U} . \mathrm{S}$. citizen, $1=$ Foreign citizen \\
\hline Employment status & $0=$ Part-time; $1=$ Full-time \\
\hline Course load & Continuous variable \\
\hline Years of prior teaching & Continuous variable \\
\hline $\operatorname{Rank}^{\mathrm{a}}$ & $\begin{array}{l}\text { Lecturer/instructor }{ }^{\mathrm{b}} \text {, Assistant professor, Associate professor, Full } \\
\text { professor }\end{array}$ \\
\hline \multicolumn{2}{|l|}{ Course characteristics } \\
\hline Course level & $0=$ Lower division, $1=$ Upper division \\
\hline General education status & $0=$ Non-general education, $1=$ General education course \\
\hline Disciplinary area $^{\mathrm{a}}$ & $\begin{array}{l}\text { Hard-pure-life, Hard-pure-non-life, Hard-applied-life, Hard-applied- } \\
\text { non-life, Soft-pure-life, Soft -pure-non-life, Soft -applied-life, Soft - } \\
\text { applied-non-life }\end{array}$ \\
\hline \multicolumn{2}{|c|}{ Institutional characteristics } \\
\hline Carnegie Classification $^{\mathrm{a}}$ & $\begin{array}{l}\text { Doctoral - Extensive, Doctoral - Intensive, Master's Colleges and } \\
\text { Universities I \& II, Baccalaureate - Liberal Arts }{ }^{\mathrm{b}} \text {, Baccalaureate - } \\
\text { General, Other classification }\end{array}$ \\
\hline Institutional control & $0=$ Public $; 1=$ Private \\
\hline
\end{tabular}


Table 1.

Disciplinary Areas by Biglan Categories

\begin{tabular}{|c|c|c|}
\hline & Hard & Soft \\
\hline $\begin{array}{l}\text { Pure- } \\
\text { Life }\end{array}$ & $\begin{array}{c}\text { Biology (general) } \\
\text { Biochemistry or biophysics } \\
\text { Botany } \\
\text { Environmental science } \\
\text { Microbiology or bacteriology } \\
\text { Zoology } \\
\text { Kinesiology }\end{array}$ & $\begin{array}{c}\text { Anthropology } \\
\text { Ethnic studies } \\
\text { Political science (incl. gov't, int'l rel.) } \\
\text { Psychology } \\
\text { Sociology }\end{array}$ \\
\hline $\begin{array}{l}\text { Pure- } \\
\text { Non-Life }\end{array}$ & $\begin{array}{c}\text { Astronomy } \\
\text { Atmospheric science (incl. meteorology) } \\
\text { Chemistry } \\
\text { Earth science (incl. geology) } \\
\text { Mathematics } \\
\text { Physics } \\
\text { Statistics }\end{array}$ & $\begin{array}{c}\text { Art, fine and applied } \\
\text { English (language and literature) } \\
\text { History } \\
\text { Language and literature (except English) } \\
\text { Music } \\
\text { Philosophy } \\
\text { Theater or drama } \\
\text { Geography }\end{array}$ \\
\hline $\begin{array}{l}\text { Applied- } \\
\text { Life* }\end{array}$ & $\begin{array}{l}\text { Medicine } \\
\text { Dentistry } \\
\text { Veterinarian } \\
\text { Pharmacy } \\
\text { Agriculture }\end{array}$ & $\begin{array}{c}\text { Theology or religion } \\
\text { Business education } \\
\text { Elementary/middle school education } \\
\text { Music or art education } \\
\text { Physical education or recreation } \\
\text { Nursing } \\
\text { Allied health/other medical } \\
\text { Social work } \\
\text { Family Studies } \\
\text { Criminal justice }\end{array}$ \\
\hline $\begin{array}{l}\text { Applied- } \\
\text { Non-Life }\end{array}$ & $\begin{array}{l}\text { Aero-/astronautical engineering } \\
\text { Civil engineering } \\
\text { Chemical engineering } \\
\text { Electrical or electronic engineering } \\
\text { Industrial engineering } \\
\text { Materials engineering } \\
\text { Mechanical engineering } \\
\text { General/other engineering }\end{array}$ & $\begin{array}{c}\text { Journalism } \\
\text { Accounting } \\
\text { Business administration (general) } \\
\text { Finance } \\
\text { Marketing } \\
\text { Management } \\
\text { Architecture } \\
\text { Urban planning } \\
\text { Economics } \\
\text { Communications } \\
\text { Public administration }\end{array}$ \\
\hline
\end{tabular}

Note: Categorization from Nelson Laird, Shoup, and Kuh (in press).

*Removed speech from HAL category. 
Table 2.

FSSE Emphasis on Deep Approaches to Learning Scale, Subscales, and Component Items

Emphasis on Deep Approaches to Learning $(\alpha=.75)$

Combination of the 3 subscales listed below

Emphasis on Higher-Order Learning $(\alpha=.73)$

Analyzing the basic elements of an idea, experience, or theory, such as examining a particular case or situation in depth and considering its components ${ }^{\mathrm{a}}$

Synthesizing and organizing ideas, information, or experiences into new, more complex interpretations and relationships ${ }^{\mathrm{a}}$

Making judgments about the value of information, arguments, or methods, such as examining how others gathered and interpreted data and assessing the soundness of their conclusions $^{\mathrm{a}}$

Applying theories or concepts to practical problems or in new situations ${ }^{\mathrm{a}}$

Emphasis on Integrative Learning $(\alpha=.69)$

Work on a paper or project that requires integrating ideas or information from various sources $^{\mathrm{b}}$

Have class discussions or writing assignments that include diverse perspectives (different races, religions, genders, political beliefs, etc.) ${ }^{\mathrm{c}}$

Put together ideas or concepts from different courses when completing assignments or during class discussions ${ }^{\mathrm{b}}$

At least once, discuss ideas from your readings or classes with you outside of class ${ }^{\mathrm{d}}$

Discuss ideas or readings from class with others outside of class (other students, family members, co-workers, etc.) ${ }^{\mathrm{b}}$

Importance of Reflective Learning ${ }^{\mathrm{b},}(\alpha=.81)$

Examine the strengths and weaknesses of their views on a topic or issue ${ }^{b}$

Try to better understand someone else's views by imagining how an issue looks from that person's perspective ${ }^{b}$

Learn something that changes the way they understand an issue or concept ${ }^{\mathrm{b}}$

\footnotetext{
${ }^{\mathrm{a}}$ Faculty were asked how much (1=Very little, 2=Some, 3=Quite a bit, 4=Very much) a selected course emphasized this.

${ }^{\mathrm{b}}$ Faculty were asked how important (1=Not Important, 2=Somewhat Important, 3=Important, 4=Very Important) it was for students to do this in a selected course.

${ }^{\mathrm{c}}$ Faculty were asked how often $(1=$ Never, $2=$ Sometimes, $3=$ Often, $4=$ Very often $)$ students in a selected course engage in this.

${ }^{\mathrm{d}}$ Faculty were asked the percentage ( $1=$ None, $\left.1.75=1-24 \%, 2.5=25-49 \%, 3.25=50-74 \%, 4=75-100 \%\right)$ of students in a selected course that did this. The item was scaled so that its range $(1-4)$ would match that of the other items.
} 
Table 3.

The Effects of Disciplinary Area and GEC Status on Faculty Emphasis on Deep Approaches to Learning $(N=8,030)$

\begin{tabular}{|c|c|c|c|c|c|c|c|c|}
\hline & \multicolumn{2}{|c|}{$\mathrm{DL}^{\mathrm{a}}$} & \multicolumn{2}{|c|}{$\mathrm{HL}^{\mathrm{a}}$} & \multicolumn{2}{|c|}{$\underline{I L}^{\mathrm{a}}$} & \multicolumn{2}{|c|}{$\underline{\mathrm{RL}}^{\mathrm{a}}$} \\
\hline & B & SE & B & SE & B & SE & B & SE \\
\hline Constant & 0.00 & 0.01 & 0.00 & 0.01 & 0.00 & 0.01 & 0.00 & 0.01 \\
\hline GEC & $0.26 * * *$ & 0.02 & 0.15 & 0.02 & $0.25 * * *$ & 0.02 & $0.22 * * *$ & 0.02 \\
\hline \multicolumn{9}{|l|}{ Academic Discipline } \\
\hline HPL & $-0.43 * * *$ & 0.04 & $-0.39 * * *$ & 0.05 & $-0.24 * * *$ & 0.04 & $-0.41 * * *$ & 0.04 \\
\hline HPN & $-0.78 * * *$ & 0.04 & $-0.19 * * *$ & 0.04 & $-0.79 * * *$ & 0.04 & $-0.85 * * *$ & 0.04 \\
\hline HAL & $-0.36 * * *$ & 0.10 & $-0.32 * *$ & 0.11 & -0.14 & 0.10 & $-0.41 * * *$ & 0.10 \\
\hline HAN & $-0.53 * * *$ & 0.06 & -0.04 & 0.06 & $-0.44 * * *$ & 0.06 & $-0.73 * * *$ & 0.06 \\
\hline SPL & 0.20 *** & 0.04 & 0.03 & 0.04 & $0.11 * *$ & 0.04 & $0.30^{* * *}$ & 0.04 \\
\hline SPN & $0.23 * * *$ & 0.03 & 0.04 & 0.04 & $0.19 * * *$ & 0.03 & $0.30 * * *$ & 0.03 \\
\hline SAL & $0.28 * * *$ & 0.04 & 0.08 & 0.04 & $0.34 * * *$ & 0.04 & $0.25^{* * *}$ & 0.04 \\
\hline \multicolumn{9}{|l|}{ Interactions Terms } \\
\hline $\mathrm{HPL}^{*} \mathrm{GEC}$ & -0.17 & 0.09 & $-0.22 *$ & 0.10 & $-0.23 * *$ & 0.09 & 0.00 & 0.09 \\
\hline $\mathrm{HPN} * \mathrm{GEC}$ & -0.14 & 0.08 & -0.15 & 0.08 & $-0.17 *$ & 0.08 & -0.04 & 0.08 \\
\hline HAL * GEC & 0.18 & 0.20 & 0.25 & 0.22 & 0.05 & 0.20 & 0.15 & 0.20 \\
\hline HAN*GEC & -0.06 & 0.11 & 0.02 & 0.12 & -0.10 & 0.11 & -0.06 & 0.11 \\
\hline SPL*GEC & -0.07 & 0.08 & -0.07 & 0.08 & -0.03 & 0.08 & -0.07 & 0.08 \\
\hline SPN*GEC & -0.08 & 0.06 & $-0.14 *$ & 0.07 & -0.05 & 0.06 & -0.02 & 0.06 \\
\hline $\mathrm{SAL} * \mathrm{GEC}$ & $-0.17 *$ & 0.08 & $-0.31 * * *$ & 0.09 & -0.14 & 0.08 & 0.00 & 0.08 \\
\hline R-squared & 0.22 & & 0.06 & & 0.23 & & 0.23 & \\
\hline F-value & 60.98 & $* * *$ & 13.87 & $* * *$ & 63.31 & $* * *$ & 64.80 & $* * *$ \\
\hline
\end{tabular}

Note: All variables were mean centered prior to entry and interaction terms were products of mean centered variables. Coefficients and standard errors were excluded for control variables (Appendix A). Those results are available upon request from the authors.

${ }^{a}$ Standardized prior to analyses. DL $=$ emphasis on deep approaches to learning, $\mathrm{HL}=$ emphasis on higher-order learning, $\mathrm{IL}=$ emphasis on integrative learning, and $\mathrm{RL}=$ importance of reflective learning. 
Table 4.

Mean Differences for Emphasis on Deep Approaches to Learning by GEC Status and Discipline

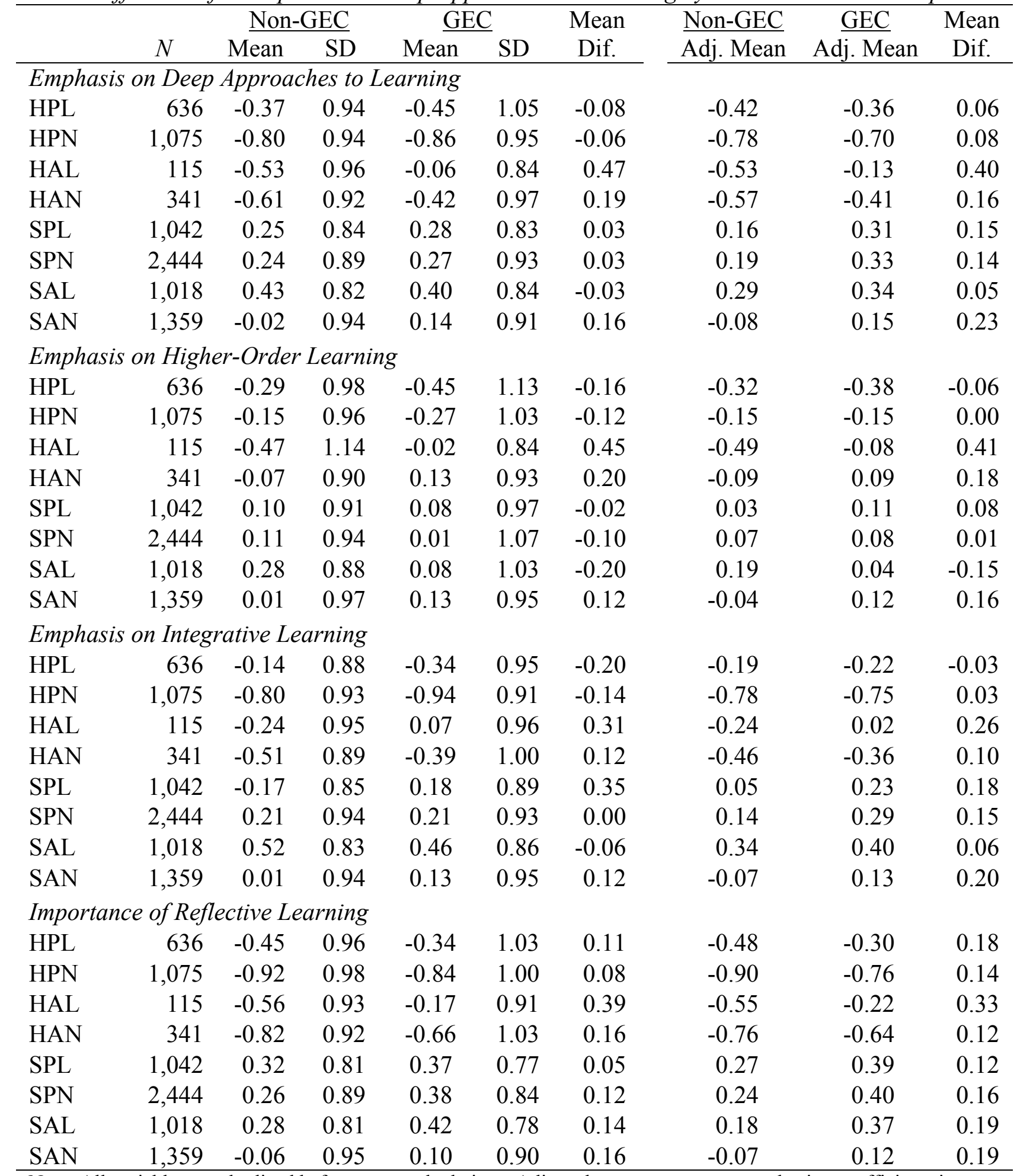

Note: All variables standardized before mean calculations. Adjusted mean scores computed using coefficients in Table 3. HPL = hard-pure-life; HPN = hard-pure-non-life; HAL= hard-applied-life; HAN = hard-applied-non-life; SPL $=$ soft-pure-life; SPN = soft-pure-non-life; SAL = soft-applied-life; SAN = soft-applied-non-life. 
The Effect of Teaching 28 